\title{
Analyzing Inter-Organization Communication between Customer and Supplier of Subsidized Paddy Fertilizer
}

\author{
Mohd Shamsuri Md Saad ${ }^{1}$, Ammar Redza Ahmad Rizal ${ }^{2} \&$ Shahrina Md Nordin $^{2}$ \\ ${ }^{1}$ Center of Language and Human Development, Universiti Teknikal Malaysia Melaka, Malaysia \\ ${ }^{2}$ Management and Humanities Department, Universiti Teknologi PETRONAS, Malaysia \\ Correspondence: Ammar Redza Ahmad Rizal, Management and Humanities Department, Universiti Teknologi \\ PETRONAS, Malaysia.E-mail: redzarizal@yahoo.com
}

Received: January 16, 2015 Accepted: January 28, 2015 Online Published: June 5, 2015

doi:10.5539/ass.v11n17p90 URL: http://dx.doi.org/10.5539/ass.v11n17p90

\begin{abstract}
Inter-Organization Communication (IOC) is a commonly used communication discipline to communicate between and among organizations. This paper aimed to investigate elements of IOC theories of communication management used between a local farmer union (PPK) and subsidised fertilizer suppliers based on the perspectives of the PPK. This study employed a quantitative method through a survey using questionnaires which were distributed to a total of 192 representatives of 63 PPKs from granary areas. The findings revealed two essential indicators to support inter-organizational communication; communication willingness and communication commitment. This study will be useful for both scholars and practitioners in further understanding the current situation of communication in subsidized fertilizer industry in Malaysia. Further study on another variables in IOC and the relationship between components/variables involved would be beneficial on expanding knowledge of inter-organizational communication.
\end{abstract}

Keywords: customer-supplier relationship, Inter organizational communication, subsidy, fertilizer

\section{Introduction}

Numerous studies have proven that communication is a powerful tool in strengthening the relationship between customers and suppliers. Communications between organizations, generally referred to as inter-organizational communication (IOC), are essentially an important factor in providing support to strengthen the relationship between two organizations (Paulraj, 2008). IOC stresses on information sharing between the two parties which is beneficial for improvement in the supplier-customer relationship (Mohr \& Navin, 1990; Ronchi, 2003). Paulraj's argument is consistent with findings by different scholars in management and marketing (e.g., Mohr \& Nevin, 1990; Mohr et al., 1996; Schultz \& Evans, 2002) which emphasize on important role of communication in fostering the relationship between organizations. A good relationship between two parties particularly between a supplier and customer ensures stability and advancement in terms of product development, cost reduction and timely and precise delivery process (Ronchi, 2003).

This study was analysing Malaysian paddy fertilizer sectors for their uniqueness. First, it is a subsidized market whereby farmers obtain fertilizer through government assistance. The Malaysian Government has been giving a great emphasis and attention on paddy plantation sector for rice is a staple food in the country. Malaysian government spends about 30 million USD annually on chemical fertilizer. However, farmers are not dealing directly with the suppliers (Malaysian NPK Fertilizer Sdn Bhd) for the procurement process. An organization known as Pertubuhan Peladang Kawasan or Local Farmers Union (PPK) are responsible in handling necessary processes from the procuring procedure up until arrangement for product delivery to farmers (LPP, 2008). Therefore, all the communication processes take place between MNF Sdn Bhd and PPK. The relationship of PPKs, government and MNF Sdn Bhd is shown in a diagram in Figure 1. Furthermore, a reliance on fertilizer usage to increase crop yield requires a good relationship fostered between farmers as customers, generally represented by farmer organizations, and manufacturers or retailers as suppliers (Zainal, 2008). 


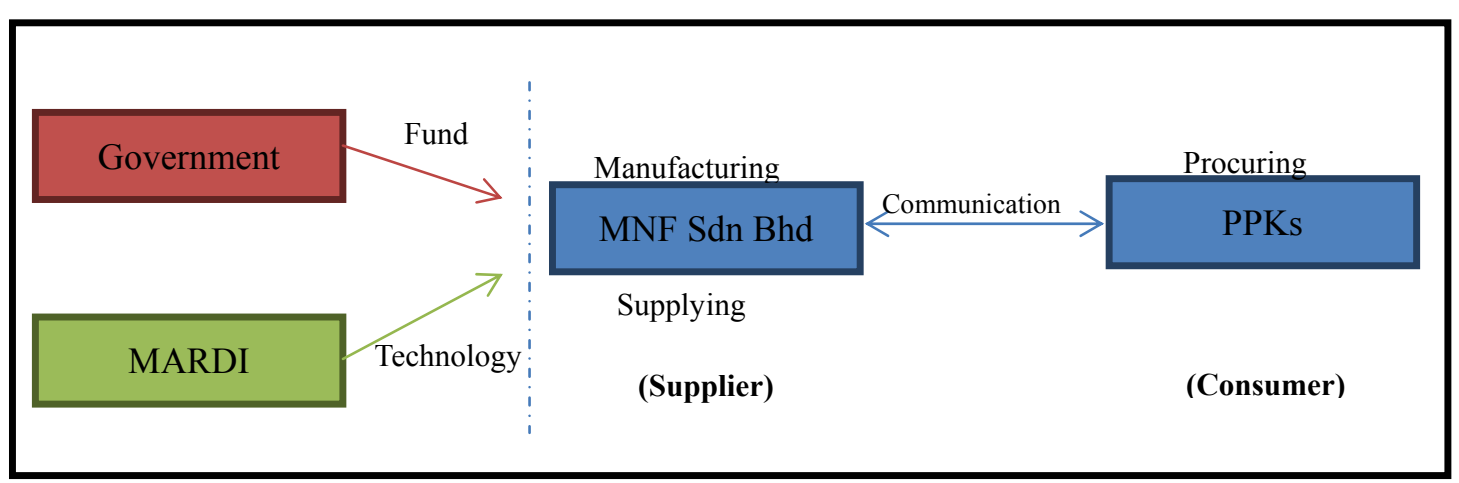

Figure 1. Communication process between supplier and customer in Malaysia Subsidized Paddy Fertilizer

Despite the rigorous efforts and initiatives by the Government, Fahmi, Abu Samah and Abdullah (2013) argue that Malaysia's rice production is still inefficient in terms of cost and production. Several issues and challenges specifically on the supply of fertilizer have impacted upon the yield of paddy. Some of the challenges in fertilizer supply revolve around the following issues (reported in Berita Transformasi Pertanian: Lahir Peladang Progresif, 2012): Eligibity of farmers receiving the fertilizer, monitoring frequency and timely distribution of fertilizer to farmers.

There is a need to ensure that the subsidized fertilizer is supplied to and received only by eligible farmers. The selection of eligible farmers is commonly done by the state Farmers Organization Authority Malaysia (Lembaga Pertubuhan Peladang)/ Area Farmers Organization (Pertubuhan Peladang Kawasan). More frequent field visit is crucial for acceptance, verification and monitoring purposes. Shahrina et al. (2013), on a similar ground, report that farmers are generally hindered from receiving the latest information which requires more frequent site visits by the relevant bodies including the suppliers.

Furthermore a timely distribution is also important. The late supply of fertilizer could result in farmers' decision to sell off the subsidized fertilizer which could result in a loss to the government. Local newspapers have reported a number of late delivery cases of fertilizer to farmers (see Zainal, 2008). In ensuring a timely delivery, the Ministry of Agriculture has recently issued a warning to suppliers in cases where the products are not delivered within a specific period of time (Noh, 2012). Otieno et al. (2012) assert that failure in delivering on time could be due to several causes including lack of information-sharing. Hence, efficient communications management between suppliers and customers is essential to help address the all the issues.

A supplier-customer relationship in a subsidized market is presumably straight-forward and would face less problems and complications as customers would just have to receive the items from the supplier without payment. However, common problems that are generally associated with market processes (e.g. late product delivery, no advancement in technology and lack of information sharing) do take place in the subsidized market. The situation could be more critical if the sole supplier does not place sufficient emphasis on the importance of information-sharing with the customers. The situation may lead to what is called as 'reverse bullwhip effect' (Otieno et al., 2012). It has been reported that 53\% of enterprises in America suffer from 'reverse bullwhip effect' due to lack of information-sharing between customers and suppliers. Although the case happens in unsubsidized market, the same situation could also happen in a subsidized market scenario. It is, hence, important to emphasize on the important role of IOC in such a relationship. The communication framework allows information to transfer and flow between the organizations.

Empirical studies on IOC have focused more on determining the facets of communication (Mohr \& Navin, 1990), evaluating suppliers' perspective (Prahinski \& Bentton, 2004) and determining the performance outcomes (Paulraj, 2008). There have not been many studies on suppliers' communication strategies towards customers in the context of subsidized market. This paper, hence, presents a conceptual framework of IOC for effective communications between customers and suppliers. Theories of IOC were discussed in this paper to form the underlying basis of the conceptual framework. The study was conducted based on the conceptual framework and its empirical findings are crucial in providing insights in customer's perception towards the IOC strategies adopted by the suppliers in the Malaysian subsidized fertilizer market for paddy plantation. The conceptual framework espoused in this paper has a theoretical significance in filling the gap in the body of knowledge within the inter-organizational communication discipline. 


\subsection{Background of Study}

In average, Malaysia produces 2.67 tan of paddy each year (DOS, 2012). However more than $60 \%$ of the production comes from the northern region where two from three largest granary areas in Malaysia are located. . Furthermore, Muda Agriculture Development Authority (MADA) alone contains around 40,000 families who work as farmers (MADA, 2007). It makes the northern region of Malaysia as one of the main rice producers in Malaysia and contains the largest number of farmers compared to other regions.

There are three major granary areas under MADA, IADA KADA. These regulatory bodies are responsible in managing farmers in terms of irrigation, planting and technical advice. Under this management authority, there are several small groups of management team known as "Pertubuhan Peladang Kawasan" or PPK (Area Farmers Organization) which is the local union of farmers in the area. Their role is managing and planning for any errands for a single planting season. Furthermore, PPKs are also responsible on managing purchase of non-subsidized fertilizer and storing the subsidized ones before the disbursement to the farmers. The PPKs are hence considered as customers in this study.

Quality communication through more frequent field visits is crucial for acceptance, verification and monitoring purposes. Nordin et al. (2014) report that farmers are generally hindered from receiving the latest information which requires more frequent site visits by the relevant bodies including the suppliers. There is also a need to ensure that the subsidized fertilizer is supplied to and received only by eligible farmers. The selection of eligible farmers is commonly done by the state Farmers Organization Authority Malaysia (Lembaga Pertubuhan Peladang)/Area Farmers Organization (Pertubuhan Peladang Kawasan).

\subsection{Literature Review}

Communication entails information sharing between two parties which could be interpersonal, intra-organization, inter-organizations or a public communication. Scholars have done numerous studies in the different disciplines of communication. Craig (1999) categorizes disciplines of communication into seven groups whereby it has become one of the indicators to sort the disciplines of communication studies. In the context of Inter Organizational Communication (IOC), the role of communication theory in this area is related to interaction between a firm and another firm. Mohr and Nevin (1990) describe IOC as "a glue that holds together a channel of distribution" (p. 36). This current section will highlight the importance of communication between firms, how theories of IOC have evolved and empirical findings from previous studies

\subsubsection{Facets of Communication}

It has been noted that communication strategy is an important element in building IOC. The development of communication strategies has been defined as facets of communication by Mohr and Navin (1990) who are among the earliest scholars in structuring the IOC theory. They conclude that communication has been studied as both a dependent (Tjosvold, 1985) and an independent variable (Kapp \& Barnett, 1983; Snyder \& Morris, 1984). Mohr and Navin (1990) also state that previous researchers tend to avoid making direct causal statements about effects of communication and effects on communication. However, there is a need to treat communication as dependent variables which explains the "effects on communication" (Mohr \& Navin, 1990). It is in agreement with Porter and Roberts (1976) where they state that the treatment of communication as a dependent variable is braced by the idea that "the total configuration of the organisation undoubtedly exerts a strong influence on the characteristics of communication within it" (p. 1570).

Thus, both communications theory and organizational theory suggest a focus on various facets of communication, including frequency, direction, willingness, modality, and content (Farace, Monge, \& Russell, 1977; Guetzkow, 1965; Jablin et al., 1987; Rogers \& Agarwala-Rogers, 1976). Furthermore, these five facets have been studied extensively by researchers in organizational communication.

\subsubsection{Communication Willingness}

A company's communication willingness refers to its openness to communicate relevant information honestly and frequently (Fawcett et al., 2007, p. 360). Different companies often have different attitudes toward information communication with their supply chain partners. Some companies are unwilling to share information, although sometimes they have to share upon a pressure from business partners (Peng et al., 2010). Information is an important resource which is able to affect market activities. In some situations, organizations are afraid that information provided to suppliers or buyers may be abused and place their organizations at a competitive disadvantage (Peng et al., 2010). According to organizational theory, company culture influences how much the will of its staff are to share information (Constant, Kiesler, \& Sproull, 1994; Al-Tameem 2004; McKinnon et al., 2003). This cultural influence holds for communication across organizations in the supply chain or 
buyers/customers - relationship as well as across internal functions such as new product development and also marketing purposes. However, different organizations may have different perspectives towards their willingness to communicate especially when it involves different background including culture, regions and religious belief (Leonard, 2009).

Mohr and Sohi (1995) report a positive relationship between norms of information exchange and specific communication flows. It appears that communication norms will encourage members' willingness to initiate and establish routines and procedures for communication. Fawcett et al. (2007) examine empirically how ICT is used to enhance supply chain and supplier - customer's relationship and performance and they find that communication willingness impacts operational performance and is critical to the development of a real information sharing capability.

Literature and past studies have stated that communication willingness will highly determine the communication between organizations (Mohr \& Nevin, 1990; Mohr \& Sohi, 1996; Fawcett et al., 2007; Peng et al., 2007). Unwillingness to share relevant information among organizations can disrupt huge investments in technology, decrease the potential values, negatively impact cooperation between organizations, and further decrease organizations' competitive edge (Lee, So, \& Tang, 2000; Fawcett et al., 2007; Mendelson, 2000), therefore making communication willingness as an important facet in inter-organizational communication.

\subsubsection{Communication Commitment}

Benefits of good communication can be measured through indirect and direct effect. Previous studies have shown that financial performance, profitability and market share are indirect effect of good communication (Amanor-Boadu, Trienekens, \& Willems, 2002). The direct effect of good communication focuses on the communication commitment between two parties (Peng et al., 2010).

Empirical study on supplier and customer relationship has documented that a support of communication is an important factor to evaluate the engagement between these two parties (Prahinski \& Bentton, 2004, Peng et al., 2010). However, past studies have also shown that different kinds of customers show different interest towards their support to the suppliers. Prahinski and Bennton (2004) further state that product quality, price, and responsiveness are among important elements which the suppliers expect over a good communication. Such argument is consistent with Peng et al. (2010) who state that support would be apparent between suppliers and customers if communication is good between them, especially on the elements of product quality, responsiveness and price. In addition, the support is even more vital in realms of new technologies. In the recent development of technology especially green technology, technology transfer should be considered as an important variable in measuring the support of communication. Polonsky (1996) and Ammar et al. (2012) assert that stakeholders in any industry are becoming more aware of improvement of green technology in the industry. They would like their voices or suggestions to be heard by the manufacturers before developing any new products or technology. Therefore, it shows that customers are interested in technology development and it should be recognized as their commitment towards communication with the suppliers.

\section{Method}

\subsection{Instrument}

The study was conducted using questionnaire as instruments where respondents were required to fill a survey form. The items were measured by using 'Likert Scale' method as it is suggested in order to evaluate the range of sample response to a statements or series of statements (Croasmun \& Ostrum, 2011). The scale used was one (1) to five (5) where 1 is strongly disagree while 5 is strongly agree. A 5 scale selection on an instruments or statements is commonly used by researchers throughout their disciplines (Croasmun \& Ostrum, 2011).

\subsection{Sampling}

The study employed a convenient sampling method as it is a common practice that a preliminary study of this kind may adopt a minimal sample method (Croasmun \& Ostrum, 2011). Thirty (30) respondents were selected from the total population. The scientific priority of any kind of sample method adopted in any social science research is justified by the level which the method can prove the representativeness of the larger population (Croasmun \& Ostrum, 2011). Respondents were selected among officers from PPKs who are in frequent contact with fertiliser supplier. The officers involved include:

a) General Manager of the said PPK.

b) Skim Baja Padi Kerajaan Persekutuan Officers - Officers who manage subsidized fertilizer from the federal government. 
c) Store Manager.

The selection of these individuals were based on their roles in the said organizations which require frequent meetings with the suppliers. According to Leornard-Barton (1995), employees who possess information on a particular subjects, techniques or dimensions are presenting the organizations knowledge database. Therefore, these individuals or groups will represent organizations when communicating or engaging with other personnel or organizations. This study avoids selecting individuals/staff who are not closely related in procuring process of the subsidized fertilizer in order to avoid error on the data collected.

\subsection{Data Collection}

The study collected data from 192 respondents throughout 63 PPKs in Malaysia. As explained earlier, the number of respondents is sufficient based on Krejcie and Morgan (1970). Figure 3.6 shows the distributions of respected PPKs. Organizations (PPK) were first contacted to set up appointment. Then, researcher personally distributed the questionnaire used to the respondents. However, to avoid bias during the data collection process, respondents answered the questionnaire forms by themselves. Afterwards, forms were collected on the same day or mailed back to the researcher using envelope provided to them during the appointment. Out of 192 questionnaires distributed, all of them were collected and no non-response forms were identified. All of the instruments used were answered completely by the respected respondents making all of it viable for statistical analysis.

Collected data were analysed for their reliability by using Cronbach-Alpha internal consistency test. Data collected were also analysed for their validity by using factor analysis. Both Cronbach-Alpha test and factor analysis were recognized as a strong analytical test for data reliability and validity (Hair et al., 2006)

\section{Result and Discussion}

\subsection{Reliability and Validity Test}

Factor analysis and reliability tests were used to validate the data. For this study, the factor analysis was done by using Statistical Product and Service Solution (IBM SPSS 20.0). Data were collected by using orthogonal varimax rotation. It was conducted to determine whether the items used in the study were loaded in the same constructs.

The analysis was conducted twice. Factor analysis for each component showed that some of the items were discarded due to their low loading in the factor as well as high loading in the other factor. Therefore, these dropped items were not used in further analysis. The discarded process is not new in the social science study. This is supported by Preacher and Hayes's (2004) report which state that the deselecting of items for a factor is important to ensure data validity in the final outcome.

In the second attempt, all the remaining items within the factors were tested again for factor analysis. This time, all items included showed high loading values above 0.60 on their respective factor. There were four items in the first factor (i.e. communication willingness), six items in the second factor (i.e. communication behavior), five items in the third factors (i.e. communication quality) and seven items in the fourth factor (i.e. communication commitment). The amount of items were viable for further analysis as Hair et al. (2006) state that three items for a single factor is acceptable and four items are recommended. The second attempt of factor analysis also showed that the measure of sampling adequacy under Kaiser-Meyer-Olkin test showed the score of 0.607 which was adequate as stated by Kaiser (1974). Furthermore, Bartlett's test of Sphericity was also significant $(<0.000)$. Details on the load factors and KMO test are shown in Table 1.

Table 1. Factor analysis test for components in this study

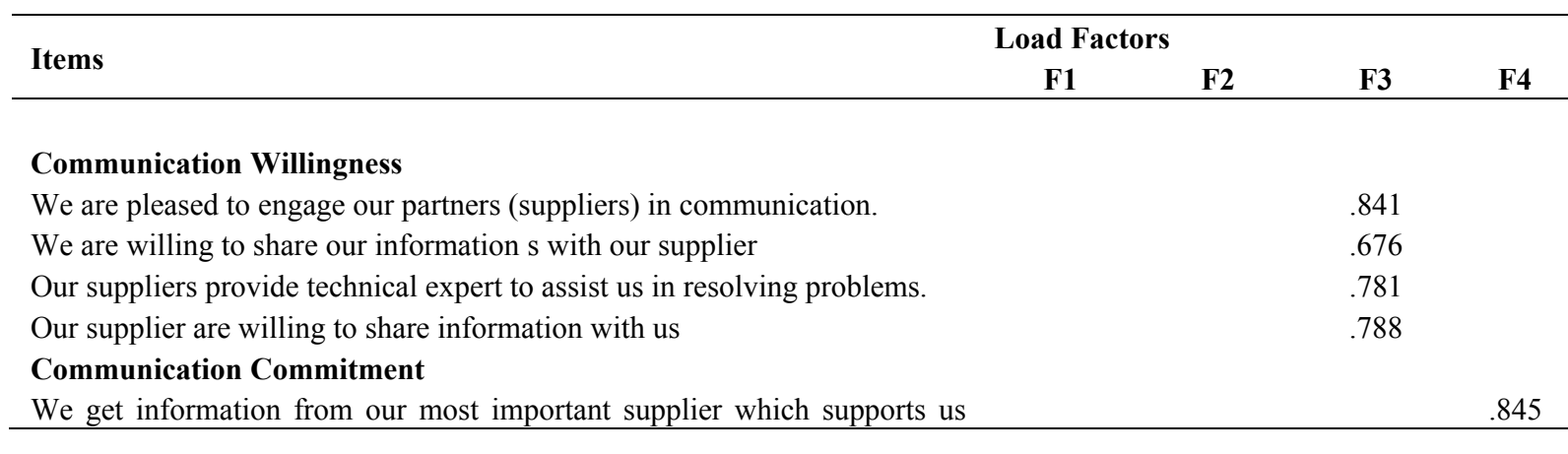




\begin{tabular}{|c|c|c|c|}
\hline \multirow{2}{*}{ Items } & \multicolumn{3}{|l|}{ Load Factors } \\
\hline & $\mathbf{F 2}$ & F3 & F4 \\
\hline \multicolumn{4}{|l|}{ directly in product quality control. } \\
\hline $\begin{array}{l}\text { We get information from our most important supplier which supports us } \\
\text { directly in product improvement. }\end{array}$ & & & .862 \\
\hline $\begin{array}{l}\text { We support our suppliers on getting the rightful information on matters } \\
\text { related to improve product quality control. }\end{array}$ & & & .915 \\
\hline $\begin{array}{l}\text { We get information from our most important supplier which supports us } \\
\text { directly in technology development }\end{array}$ & & & .696 \\
\hline $\begin{array}{l}\text { We support our suppliers on getting the rightful information on matters } \\
\text { related to technology development. }\end{array}$ & & & .776 \\
\hline $\begin{array}{l}\text { We support our suppliers on getting the rightful information on matters } \\
\text { related to product improvement. }\end{array}$ & & & .934 \\
\hline $\begin{array}{l}\text { We support our suppliers on getting the rightful information on matters } \\
\text { related to improve the project success rate. }\end{array}$ & & & .953 \\
\hline Kaiser-Meyer-Olkin (KMO) Measure of Sampling Adequacy & .607 & & \\
\hline Approx. Chi Square & 2922.499 & & \\
\hline Bartlett's Test of Sphericity & 105 & & \\
\hline Sig. & .000 & & \\
\hline
\end{tabular}

Instrument's reliability and internal consistency test were employed. Cronbach's Alpha test was conducted to obtain the instrument reliability coefficient. Cronbach's Alpha score for each instruments ranged from 0.819 to 0.939. The score showed that instruments used for this study were internally consistent and reliable. The Cronbach's Alpha score is shown in Table 2.

Table 2. Cronbach's alpha score

\begin{tabular}{lcc}
\hline Factor & No of Items & Cronbach's Alpha Score \\
\hline Communication Willingness & 4 & 0.819 \\
Communication Commitment & 7 & 0.939 \\
\hline
\end{tabular}

\subsection{Analysis on the IOC Component}

For communication willingness dimension, it can be deduced from the descriptive analysis (see Table 3 ) that most respondents are willing to share information with the suppliers (4.18). Willing to communicate is an important factor to propel IOC to be successful in any communication activities between organizations. By having willingness, an organization shows its intention to share information with the other parties. Moreover, this statement is supported by empirical findings which show most of the respondents agree that their suppliers' are willing to share information with them (4.12). Information is considered important resource where it could affect the market activities. In some situations, organizations are afraid that information provided to suppliers or buyers may be abused and place their organizations at a competitive disadvantage (Peng et al., 2010).

Table 3. Mean score and standard deviation of items used in communication willingness

\begin{tabular}{|c|c|c|c|}
\hline Variable & Items/Components & $\begin{array}{l}\text { Mean } \\
\text { Score }\end{array}$ & $\begin{array}{l}\text { Standard } \\
\text { Deviation }\end{array}$ \\
\hline \multirow{6}{*}{$\begin{array}{l}\text { Communication } \\
\text { Willingness }\end{array}$} & $\begin{array}{l}\text { We are pleased to engage our partners (suppliers) in } \\
\text { communication. }\end{array}$ & 4.56 & 0.742 \\
\hline & We are willing to share our information s with our supplier & 4.18 & 0.694 \\
\hline & $\begin{array}{l}\text { Our suppliers provide technical expert to assist us in } \\
\text { resolving problems. }\end{array}$ & 3.70 & 1.198 \\
\hline & Total (Average Score) & 4.12 & 0.869 \\
\hline & Mean & & Standard Deviation \\
\hline & 4.14 & & 0.875 \\
\hline
\end{tabular}


Communication commitment is an indicator to determine organizations commitment towards IOC in different sectors inside their organizations. Communication commitment includes issues related to problem resolution, product quality, product improvement, technology adaptation and efficiency of delivery. Respondents agreed that they support their suppliers support them in product quality control (3.69) (refer Table 6) and they also support suppliers on the said matter (3.51). However, respondents stated that they do not get sufficient commitment from the suppliers in terms of product improvement (3.44). The inability of suppliers to acknowledge these consumers as important stakeholders would affect the usability and adaptation of the future products by the consumer (Polonsky, 1996). Respondents stated that that both of suppliers and themselves show communication commitment towards technology adaptation and efficiency of delivery as shown in table 6 below. With cooperation from both parties of suppliers and consumers, several problems such as late product delivery can be resolved. Furthermore, a commitment to adapt new technology will enhance future product improvement by the suppliers itself as the barriers have been diminished. Polonsky (1996) states that organizations and personnel tendency in choosing a traditional method contribute to lack of innovations in certain sectors.

Table 4. Mean score and standard deviation of items in communication commitment

\begin{tabular}{|c|c|c|c|}
\hline Variable & Items/Components & Mean Score & $\begin{array}{l}\text { Standard } \\
\text { Deviation }\end{array}$ \\
\hline \multirow{7}{*}{$\begin{array}{l}\text { Communication } \\
\text { Commitment }\end{array}$} & $\begin{array}{l}\text { We get information from our most important } \\
\text { supplier which supports us directly in } \\
\text { product quality control. }\end{array}$ & 3.69 & 0.762 \\
\hline & $\begin{array}{l}\text { We get information from our most important } \\
\text { supplier which supports us directly in } \\
\text { product improvement. }\end{array}$ & 3.44 & 0.990 \\
\hline & $\begin{array}{l}\text { We support our suppliers on getting the rightful } \\
\text { information on matters related to improve } \\
\text { product quality control. }\end{array}$ & 3.51 & 0.932 \\
\hline & $\begin{array}{l}\text { We get information from our most important } \\
\text { supplier which supports us directly in } \\
\text { technology development }\end{array}$ & 3.40 & 0.832 \\
\hline & $\begin{array}{l}\text { We support our suppliers on getting the rightful } \\
\text { information on matters related to technology } \\
\text { development. }\end{array}$ & 3.40 & 0.910 \\
\hline & $\begin{array}{l}\text { We support our suppliers on getting the rightful } \\
\text { information on matters related to product } \\
\text { improvement. }\end{array}$ & 3.64 & 1.014 \\
\hline & $\begin{array}{l}\text { We support our suppliers on getting the rightful } \\
\text { information on matters related to improve } \\
\text { the project success rate. }\end{array}$ & 3.70 & 0.939 \\
\hline
\end{tabular}

Total (Average Score)

$\mathbf{N}$

192
Mean

3.54
Standard Deviation

0.911

\subsection{Discussion}

It is well documented by the various scholars and studies in communication involving government agencies where the communication process involve more top-down and one way communication (Eshuis et al., 2014; Castells, 2013; Jami \& Walsh, 2014). Communication order will come from the top authority to be implement by the lower level agencies. However, the communication norm (top-down communication) could produce communication error, increase noise and misunderstanding. Pfeffermann et al. (2014) stated that communication play an important role in diffusing and disseminating new technology, procedures or techniques. The 
communication process need to be frequently employed and must be a two way communication rather than just order and execute. In the context of this study, it shows that there are a huge room for improvement especially when it is statistically proven that communication behavior play an important aspect in determining the organizations communication commitments'

The communication process as describe in the communication commitment dimension besides focusing on timely delivery and product quality control, it also involve product improvement and technology development. This two important concept of innovation require not only good communication process but the best communication channels to facilitate the information transfer. Communication channels according to Miller (2001) is highly depend on its user/receiver. Where there is not a single communication channels can cater or satisfy different kind of receiver. The preference of communication channels are dependent on the receiver background, age, psychographic as well as their intellectual level (Miller, 2001).

\section{Conclusion}

Throughout the study, there are several important key highlights that need to be addressed. The findings revealed two key indicators to support inter-organizational communication; communication willingness and communication commitment. The highlights include practices and current scenarios based on the context of this study. Finding from the key highlight will be useful for both scholars and practitioners in further understanding the current situation of communication in subsidized fertilizer industry in Malaysia. Further study on another variables in IOC and relationship between components/variables involved would be beneficial on expanding knowledge of inter-organizational communication.

\section{Acknowledgements}

Special thanks to Ministry of Education (Formally known as Ministry of Higher Education) Malaysia for funding this research under OneBAJA ${ }^{\mathrm{TM}}$ Long Term Research Grant Scheme. The authors would also like to express gratitude to the Management of Universiti Teknologi PETRONAS for all the support given.

\section{References}

Agarwala-Rogers, R., \& Rogers, E. M (1976). Communication in organizations. New York: Free Press

Al-Tameem, A. A. (2004). An inhibiting context hampering role of information technology as an enabler in organizational learning. Journal of Computer Information Systems, 44(4), 34-40.

Amanor-Boadu, V., Trienekens, J., Willems, S., Trienekens, J. H., \& Omta, S. W. F. (2002). Information and communication technologies, strategic power and inter-organisational relationships. In Paradoxes in food chains and networks. Proceedings of the Fifth International Conference on Chain and Network Management in Agribusiness and the Food Industry, Noordwijk, Netherlands, 6-8 June 2002 (pp. 908-918). Wageningen Academic Publishers.

Ambrose, E., Marshall, D., Fynes, B., \& Lynch, D. (2008). Communication media selection in buyersupplier relationships. International Journal of Operations \& Production Management, 28(4), 360-379. http://dx.doi.org/10.1108/01443570810861561

Ammar Redza, A. R., Shahrina, M. N., Shamsuri, M. S., \& Kamariah, I. (2012). Engagement Strategies for Stakeholder Management in New Technology Development in the Fertilizer Industry - A Conceptual Framework. World Academy of Science, Engineering and Technology, (71), 90-96.

Anderson, E., Lodish, L. M., \& Weitz, B. A. (1987). Resource allocation behavior in conventional channels. Journal of marketing Research, 85-97. http://dx.doi.org/10.2307/3151756

Brown, J. (1981). A Cross-Channel Comparison of Supplier-Retailer Relations. Journal of Retailing, 57(Winter), $3-18$.

Castells, M. (2013). Communication power. Oxford University Press.

Constant, D., Kiesler, S., \& Sproull, L. (1994). What's mine is ours, or is it? A study of attitudes about information sharing. Information Systems Research, 5(4), 400-421. http://dx.doi.org/10.1287/isre.5.4.400

Craig, R. T. (1999). Communication theory as a field. Communication theory, 9(2), 119-161. http://dx.doi.org/10.1111/j.1468-2885.1999.tb00355.x

Department of Statistics Malaysia. (2012). Selected Agricultural Indicators. Retrieved from http://www.statistics. gov.my/portal/download_Agriculture/files/Selected_Agricultural_Indicators_Malaysia_2012.pdf

Eshuis, J., Klijn, E. H., \& Braun, E. (2014). Place marketing and citizen participation: branding as strategy to 
address the emotional dimension of policy making? International Review of Administrative Sciences, 80(1), 151-171. http://dx.doi.org/10.1177/0020852313513872

Farace, R. V., Monge, P. R., \& Russell, H. H. (1977). Comunicating and organizing. Massachusetts: Addison-Wesley.

Fawcett, S. E., Osterhaus, P., Magnan, M. G., Brau, C. J., \& McCarter, W. M. (2007). Information sharing and supply chain performance: the role of connectivity and willingness. Supply Chain Management, 12(5), 358-368. http://dx.doi.org/10.1108/13598540710776935

Gaski, J. F. (1984). The theory of power and conflict in channels of distribution. The Journal of Marketing, 9-29. http://dx.doi.org/10.2307/1251326

Gaski, J. F., \& Nevin, J. (1985). The Differential Effects of Exercised and Unexercised Power Sources in a Marketing Channel. Journal of Marketing Research, 22, 130-42. http://dx.doi.org/10.2307/3151359

Grabner, J., \& Rosenberg, L. J. (1969). Communication in Distribution Channel Systems. In L. W. Stem (Ed.), Distribution Channels: Behavioral Dimensions. New York: Houghton-Mifflin Company

Guetzkow, H. (1965). Communications in Organizations. In J. March (Ed.), Handbook of Organizations (pp. 534-573). Chicago: Rand McNally and Company.

Hair, J. F. Jr., Black, W., C., Babin, B. J., Anderson, R. E., \& Tatham, R. L. (2006). Multivariate data analysis (6th ed.). New Jersey: Prentice Hall

Hendricks, K. B., \& Singhal, V. R. (2003). The effect of supply chain glitches on shareholder wealth. Journal of Operations Management, 21(5), 501-522. http://dx.doi.org/:10.1016/j.jom.2003.02.003

Jablin, F. (1987). Formal Organization Structure. In F. Jablin et al. (Eds.), Handbook of Organizational Communication: An Interdisciplinary Perspective (pp. 389-419). Newbury Park, CA: Sage Publications.

Jami, A. A., \& Walsh, P. R. (2014). The role of public participation in identifying stakeholder synergies in wind power project development: The case study of Ontario, Canada. Renewable Energy, 68, $194-202$. http://dx.doi.org/10.1016/j.renene.2014.02.004

Jaworski, B. J., \& Kohli, A. K. (1993). Market orientation: antecedents and consequences. The Journal of marketing, 53-70. http://dx.doi.org/10.2307/1251854

John, G., Ruekert, R., \& Churchill, G. A. Jr. (1983). The Interrelationships of Role Perceptions in Channels of Distribution. Working Paper, 1-83-1. Graduate School of Business, University of Wisconsin-Madison.

Jonsson, P., \& Zineldin, M. (2003). Achieving high satisfaction in supplier-dealer working relationships. Supply Chain Management: An International Journal, 8(3), 224-240. http://dx.doi.org/10.1108/1359854031048 4627

Kapp, J. E., \& Barnett, G. A. (1983). Predicting organizational effectiveness from communication activities: A multiple indicator model. Human Communication Research, 9(3), 239-254. http://dx.doi.org/10.1111/j. 1468-2958.1983.tb00697.x

Krejcie, R. V., \& Morgan, D. W. (1970). Determining sample size for research activities. Educational and psychological measurement, 30(3), 607-610.

Lee, H. L., So, K. C., \& Tang, C. S. (2000). The value of information sharing in a two-level supply chain. Management science, 46(5), 626-643. http://dx.doi.org/10.1287/46.5.626.12047

Leonard, T. J. (2009). The Gospel of Spiritualism: A Study of Seminary Students and Their Call to the Ministry. President and Editor's Note, 33.

Liker, J. K., Kamath, R. R., Wasti, S. N., \& Nagamachi, M. (1995). Integrating suppliers into fast-cycle product development. Engineered in Japan, 152-191.

McKinnon, J. L., Harrison, G. L., Chow, C. W., \& Wu, A. (2003). Organizational culture: association with commitment, job satisfaction, propensity to remain, and information sharing in Taiwan. International Journal of Business Studies, 11(1), 25-44.

Mendelson, H. (2000). Organizational architecture and success in the information technology industry. Management Science, 46(4), 513-529. http://dx.doi.org/10.1287/46.4.513.12060

Miller, K. (2001). Communication Theories: Perspectives, Processes, and Contexts. McGraw-Hill Higher Education. 
Mohr, J. J., \& Sohi, R. S. (1995). Communication flows in distribution channels: impact on assessments of communication quality and satisfaction. Journal of Retailing, 71(4), 393-416. http://dx.doi.org/10.1016/ 0022-4359(95)90020-9

Mohr, J. J., Fisher, R. J., \& Nevin, J. R. (1996). Collaborative communication in interfirm relationships: moderating effects of integration and control. The Journal of Marketing, 103-115. http://dx.doi.org/10. $2307 / 1251844$

Mohr, J., \& Nevin, J. R. (1990). Communication strategies in marketing channels: a theoretical perspective. The Journal of Marketing, 36-51. http://dx.doi.org/10.2307/1251758

Muda Agriculture Development Authority. (2007). MADA's Annual Report 2007. Retrieved from http://www.mada.gov.my/moa_mad-theme/tender/2007.pdf

Narver, J. C., \& Slater, S. F. (1990). The effect of a market orientation on business profitability. The Journal of Marketing, 20-35. http://dx.doi.org/10.2307/1251757

Noh, O. (2012, December). Government Statements on Late Delivery of Fertilizer. Speech presented at the Press Conference, MOA, Putrajaya, Malaysia.

O'Reilly, C., Chatman, J., \& Anderson, J. (1987). Message Flow and Decision Making. In F. Jablin et al. (Eds.), Handbook of Organizational Communication: An Interdisciplinary Perspective (pp. 600-623). Newbury Park, CA: Sage Publications, Inc.

Otieno, T. O., Ondiek, G. O., \& Odera, O. (2012). Factors causing reversed bullwhip effect on the supply chains of Kenyan firms. European Journal of Business and Management, 4(5), 123-130.

Paulraj, A., Lado, A. A., \& Chen, I. J. (2008). Inter-organizational communication as a relational competency: antecedents and performance outcomes in collaborative buyer-supplier relationships. Journal of Operations Management, 26(1), 45-64. http://dx.doi.org/10.1016/j.jom.2007.04.001

Peng, G., Trienekens, J. H., Omta, S. W. F., \& Wensheng, W. (2010). Inter-organizational communication in Food Supply Chains: Main facets and their Interrelationships.

Pfeffermann, N., Minshall, T., \& Mortara, L. (2014). Strategy and Communication for Innovation. Springer.

Polonsky, M. J. (1996). Stakeholder management and the stakeholder matrix: potential strategic marketing tools. Journal of Market-Focused Management, 1(3), 209-229. http://dx.doi.org/10.1007/BF00190039

Porter, L., \& Roberts, K. (1976). Communication in Organizations. In M. Dunnette (Ed.), Handbook of Industrial and Organizational Psychology (pp. 1553-1589). Chicago: Rand McNally and Company.

Prahinski, C., \& Benton, W. C. (2004). Supplier evaluations: communication strategies to improve supplier performance. Journal of Operations Management, 22(1), 39-62. http://dx.doi.org/10.1016/j.jom.2003. 12.005 .

Preacher, K. J., \& Hayes, A. F. (2004). SPSS and SAS procedures for estimating indirect effects in simple mediation models. Behavior Research Methods, Instruments, \& Computers, 36(4), 717-731. http://dx.doi.org/10.3758/BF03206553

Reve, T., \& Stern, L. W. (1986). The relationship between interorganizational form, transaction climate, and economic performance in vertical interfirm dyads. Marketing channels: Relationships and performance, $75-102$.

Robicheaux, R., \& El-Ansary, A. (1976). A General Model of Understanding Channel Member Behavior. Journal of Retailing, 52, 13-30, 93-94.

Ronchi, S. (2003). The Internet and the customer-supplier relationship. Ashgate Pub Limited.

Ruekert, R., \& Churchill, G. A. Jr. (1984). Reliability and Validity of Alternative Measures of Channel Member Satisfaction. Journal of Marketing Research, 226-233. http://dx.doi.org/10.2307/3151706

Schultz, R. J., \& Evans, K. R. (2002). Strategic collaborative communication by key account representatives. The Journal of Personal Selling and Sales Management, 23-31. http://dx.doi.org/10.1080/08853134. 2002.10754290

Shahrina, M. N., Shamsuri, M. S., \& Shuhaida, M. N. (In Press). Innovation Diffusion of New Technologies in the Malaysian Paddy Fertilizer Industry. Procedia Social and Behavioral Sciences. http://dx.doi.org/10. 1016/j.sbspro.2013.12.542 
Snyder, R., \& Morris, J. (1984), Organizational Communication and Performance. Journal of Applied Psychology, 69(August), 461-465. http://dx.doi.org/10.1037/0021-9010.69.3.461

Stern, L., \& El-Ansary, A. (1988). Marketing Channels. Englewood Cliffs, N.J.: Prentice-Hall, Inc.

Stohl, C., \& Redding, W. C. (1987). Messages and Message Exchange Processes. In F. Jablin et al. (Eds.), Handbook of Organizational Communication: An Interdisciplinary Perspective (pp. 451-502). Newbury Park, CA: Sage Publications, Inc.

Storer, C. (2006). ICTs used to coordinate food chains. Australsian agribusiness review, 14, 1-23.

Storer, C. E. (2005). Inter-organizational information management systems and relationships in agribusiness food chains of organizations. Graduate School of Business, Curtin University of Technology

Takeishi, A. (2001). Bridging inter - and intra - firm boundaries: Management of supplier involvement in automobile product development. Strategic Management Journal, 22(5), 403-433. http://dx.doi.org/10. $1002 / \mathrm{smj} .164$

Tjosvold, D. (1985). Power and Social Context in Superior-Subordinate Interaction. Organizational Behavior and Human Decision Processes, 35(June), 281-93. http://dx.doi.org/10.1016/0749-5978(85)90025-1

Zainal, A. M. (2008, December 16-18). The Malaysian Fertilizer Market. IFA Crossroads Asia-Pacific 2008, Melbourne, Australia.

\section{Copyrights}

Copyright for this article is retained by the author(s), with first publication rights granted to the journal.

This is an open-access article distributed under the terms and conditions of the Creative Commons Attribution license (http://creativecommons.org/licenses/by/3.0/). 